\title{
Mediated Ritual on Academic Ground
}

\author{
Neal King
}

\section{Invasion of Sacred Space}

In the days following a gunman's rampage in April, 2007, departments at Virginia Tech convened to discuss the losses of students and colleagues, the upcoming resumption of school, and requests from journalists to bring cameras to class. This last choice evoked a ceremonial language among faculty who usually discuss their work in more instrumental terms. Some dismissed journalists as parasitic intruders and demanded that classrooms be treated as "healing," "sacred space" free of their taint. This short essay ponders the souring of a collegial relationship among storytelling professions in the aftermath of an event that drew wide coverage.

The eruption of violence left university members scrambling for news, first about the nature of the incident, and then about the fates of people they knew. Broadcast, cable, and internet outlets assumed more central places in our lives than they usually enjoy. Though the campus newspaper provided a clearinghouse for announcements, its server crashed under the pressure of global demand, leaving private news companies, with their greater resources, to supply news even to those who worked where shots were fired. The speed at which commercial reporting conveys images and relays statements made it useful to locals as events unfolded. The incident was mass mediated for those nearby because fast capitalism trumped state channels and friendship networks.

But the reporters who respond to these demands compete for advertisers' dollars, which dangle before them in such huge numbers that journalists approach survivors en masse. Virginia Tech sprouted forests of satellite dishes; cameras surrounded survivors; and reporters inundated relatives with requests for their time. Many locals developed a siege frame of mind; so that by the time national politicians gathered for a local memorial, ambivalence about exposure had begun to rise. Handwritten signs told camera crews to leave ("Hokie Nation needs to heal. Media stay away," said one version); and the administration followed suit with requests that reporters stay out of campus buildings.

Though the ceremonial language of "sacred space" inspires speculation at the end of the essay, much of the offense taken by educators to journalists seems easy to explain. In the aftermath of group death, professional norms require reporters to swarm the living and shoot footage of anyone choked with emotion. The rapid progress of events impels them to gain access quickly, via entreaty and intrusion. Famed anchors left phone mail for grieving kin and sent flowers (and lackeys) to homes at all hours. Many locals spoke in grim humor of the cameras and boom mikes that hovered when mourners neared tears. Reporters grew aware of this reaction to their work and made enquiries in the hushed tones of undertakers.[1] In search of footage not facts, would-be interviewers were easily dismissed by agreements to talk off camera; but the courting of kin of the fallen was harder to avoid. Some surviving families had friends run interference, standing watch over houses to intercept callers. Others abandoned their homes.

Such coverage of disaster can outrage those who feel their grief made spectacle for distant masses, even if they value the more caring attention that the exposure makes possible. During the reporters' visit to campus, group boundaries clarified and many faculty began to express an oppositional logic:

\begin{tabular}{|c|c|}
\hline Education & Journalism \\
\hline Enculturation & Exploitation \\
\hline Sacredness & Profanity \\
\hline Belonging & Intrusion \\
\hline
\end{tabular}


With these polarities, teachers could scorn the journalists whose profit-seeking work threatened to prolong the trauma. We who had seen our students and teachers victimized at the start of the week could at least rise against this new imposition. Nevertheless, faculty and journalists came to share at least a few goals in this aftermath, in that reporters not only spread news and provide attention but also mediate civil religion. I next discuss the ways in which professional norms combined with communal impulses to shift faculty responses to journalists from reliance and solidarity to outrage within days.

\section{| Civil Religion through Mass Media}

Shortly after the shooting, faculty were drawn to civic rituals - the public gatherings in which crowds focus on objects of totemic significance (mass death and killers prominent among them) and engage in activities that communicate emotion.[2] By such ritual means they generated solidarity; and media broadcast allowed for people far away to share in the contagious mood. Those people in turn expressed support back to those at the ritual center. Because faculty at Virginia Tech took comfort at having been contacted in this way by people around the world, and because journalists on the scene could share in the infectious mood, members of these professions found themselves aligned in their activities and goals for a short time, despite the disparities in their professional and communal needs.

Marvin (2002) notes that rituals of civil religion tell stories that celebrate the sacred and untouchable, and thus constitute the totems that symbolize groups (pp. 204-05). The most potent rituals include stories that celebrate sacrifices made for those groups, featuring such figures as the innocent young (whose deaths states avenge if they can), the confessed guilty who suffer punishment, and the willing soldiers sent to battle. Virginia Tech's violence produced some of these elements_-blameless victims and fallen heroes-though no criminal left alive to punish. Thus, university officials and journalists worked together to foster civic bonding.

Marvin (2002) outlines the criteria of successful rituals, most of which reporters met by their framing of the violence at Virginia Tech (p. 207). By approaching the story from these angles, journalists aligned themselves with locals in their veneration of the slain.

1. Sacrifices must declare themselves willing. Reporters focused upon stories of engineering faculty who waded into danger and died protecting students, but paid less attention to the nearby class that barred its door and escaped unscathed.

2. Group members must agree on the propriety of the sacrifice. The killer at Virginia Tech took his own life, usurping the right of the state to do it for him. He failed to affirm state killing power and thus sapped the strength of this media event as civil ritual. Still, the appropriateness of that death went unquestioned in public; and pundits' commentary on the killer's background and apparent mind-state suggested that he ought to have been punished with incarceration before.[3]

3. The outcome of the ritual must be genuinely uncertain. Though the violence was over before the public knew of it, audiences waited days to learn the names of the deceased, the motive of the killer, and whether an accomplice remaineddelays that drew rapt attention and maintained uncertainty.

4. The ritual must have a definite end and beginning. The announcements of answers to questions mentioned above, and the resumption of classes the following week, marked the end of most coverage. Final ceremonies took place with assurance that the event was drawing to a close. Those rituals were reprised briefly during graduation the next month, after which the university cleared most memorial sites and reopened parts of Norris Hall.

5. The sacrifice must be valuable. Most rituals named the deceased; and the displays and reportage reproduced their smiling photos, recounted their personal attributes, and listed contributions that they had or would have made.

Because news companies benefit from coverage of drama, they tend to frame events in a manner that fosters ritual. Reporters found many ways to emphasize such aspects of the event; and though the attention paid to Virginia Tech did not make for the fullest ritual veneration of civil sacrifice, it came close enough to have generated regional solidarity. People donned school colors, cheered politicians, and planted U.S. flags at memorial spots—pairing the red stripes that recall the blood of fallen soldiers with the turkeys that stand for the university. In these ways, the rituals magnified by the media attention helped to boost solidarity on campus. As a result of that attention, faculty found themselves, improbably, central to a national event. At their most comic, tales of this bright spot in a sickening week blurred lines between gratitude and pride. (Hallway chatter: I heard from people I haven't seen in years. Well, I have email from colleagues in Europe. Why, I got a note from Hong Kong!) 
I do not mean that faculty acted as one. Reportage of large gatherings can suggest greater attendance than occurs. Many faculty likely restricted their roles in mediated events to leaving the TV news on longer or checking internet outlets more often than they otherwise might. Indeed, university faculty tend to remain aloof from national ceremony and display, distancing themselves from the more passionate (and trusting) mass at times of national crisis (Collins 2004:63-4). But Hokie spirit (no easy sell to status conscious professionals at most times, with its folksy name, garish colors, and musclebound fowl as mascot) suffused this group that week, mixing with grief. The killer had made it easy to assemble under the rubric by restricting his attacks to school buildings; but Virginia Tech also controls the best resources for local assembly: public spaces, established symbols, and e-mail networks that form the infrastructure of regional identity. The principal ceremony (a day after the shootings) that gathered national politicians in a basketball stadium drew tens of thousands, both from the surrounding community and from ranks of parents come to pick kids up from school. The larger point is that faculty were both given valuable information, and drawn into rituals of campus solidarity, in ways that corporate journalists augmented with the resources at their disposal.

With the encouragement of officials, faculty did much storytelling of our own, in op-ed pieces, interviews with reporters, and in classrooms the week after the shooting. Instructors across the nation were keen to use the event as "teaching moment," in order that students might learn from the compelling event. Substantive discussions included analyses of the killer's motives and the school's response. University-sponsored guidelines for Tech faculty encouraged a counseling orientation once classes resumed, including validations of students' feelings and referrals to the health center. For the sake of encounters with reporters at graduation, officials made available such talking points as the following: "A terrible tragedy happened here of horrific proportions, and while we must live with this memory and knowledge, we will persevere," and "Hokie Spirit will enable us to prevail in the face of tragedy and grow stronger as we move forward together." Thus, like reporters, did faculty and university officials order events into narratives that served institutional purposes, including those of the rituals that foster solidarity.

For all of those means of alignment, though, faculty and journalists differed in their institutional loyalties, which led to the conflict deeper than that caused by camera crews alone.

\section{Institutional Conflict}

The most serious threats to faculty solidarity came from stories that emphasized loony bloodshed and police failure over and above noble sacrifice. On these points, journalists' and teachers' interests diverged. As workers for profit-seeking companies, journalists not only augment solidarity in times of crisis but also violate the ethics of community and security as they craft dramas that promote their enterprise.

The publication and broadcast of images of grief place reporters at the center of rituals and storytelling, as mediators of information, as interpreters of events, and as teachers of the rules of mourning (Walter, Littlewood, and Pickering 1995;585; Cottle 2006:427; Sumiala-Seppanen and Stocchetti 2007:340). During such media events, for instance, viewers observe how others handle grief; and the implicit moral instruction becomes part of a larger "invigilation" of emotion (Walter, et al. 1995), in which bystanders learn to "deploy the appropriate attitude, the right mindset, even the right emotions" (Sumiala-Seppanen and Stocchetti 2007). Disaster coverage tends to activate and shape proprietary feelings about how to handle grief in public. Thus can journalists assume teaching roles.

The role that reporters play in such interpretation and invigilation can draw fire from academics who might regard themselves as the more proper instructors. For example, Liebes (1998) argues that

the shared collective space created by disaster time-out, zooming in on victims and their families, is the basis not for dignity and restraint but for the chaotic exploitation of the pain of participants on screen, and for the opportunistic fanning of establishment mismanagement, neglect, corruption, and so on (pp. 75-6).

Thus did many faculty come to feel in the aftermath of the violence at Virginia Tech, as journalists first dramatized the possibility of neglect by the administration of security, and then broadcast aggrandizing images from the killer's press kit that could provide fodder for copycats. "The Virginia Tech Massacre" became a tagline on television, threatening to "brand" the university with the most stigmatized terms, at just the moment that coverage of the aftermath was teaching audiences to identify with endangered students.

In his analysis of disaster marathon, Liebes (1998) notes that professional norms lead journalists to feature 
opposition views rather than rally around national leaders as they do during most media events (p. 73). The rush of concern and demand for details sends reporters in hasty search, which precludes the careful research that can shed light on social forces (Liebes:75). Many outlets demand 24-hour coverage in competition with others, in situations in which officials take days to share the most prized knowledge (Rohlinger 2007:139). While they wait for more information about the causes of disasters, reporters not only harass survivors and focus on grief, but also seize nearby prey in their search for people to blame, beginning with the authorities most directly in view. Thus did they tar the university with epithets related to bloodshed, calling its governance into question. This search for villains can frustrate locals by fulfilling the wishes of mass murderers, who usually meant either to shame authorities or to gain infamy (Liebes 1998:75).[4]

In the case of Virginia Tech, journalists gave airtime and column inches to those who blamed police for not stopping the gunman (by "locking down" campus or profiling and jailing the unstable).[5] Indeed, Liebes summarizes this tension in disaster marathons:

Whereas the principle of broadcast ceremony is to highlight emotions and solidarity and to bracket analysis, a disaster marathon constitutes a communal public forum where tragedy is the emotional motor which sizzles with conflict, emphasizing anxiety, argument, and disagreement (Liebes:76).

In this environment, group boundaries grow clear and opposition strengthens. Handgun enthusiasts demanded repeal of laws that ban firearms from campus, valorizing handguns as symbols of self-protective manhood and goodness against evil.[6] The faculty who spoke up in public rejected these bids, demanding that classrooms remain pure of arms. Thus does a disaster marathon nurture opposition alongside the solidarity, and thus did journalists compete with and offend local storytellers.

Both journalists and scholars provide perspective and guide display of emotion. We can call those lessons enculturation or exploitation, the spread of knowledge or the sale of sensation. Though some stories are more empirically grounded than others, and may spring from all manner of loyalties (to the analysis of capitalism as the exploitation of workers, for instance, vs. service to a capitalist corporation), each of us can think of reasons to emphasize conflict, to criticize authority, and to speak to the victims of social forces. Journalists do this in profitseeking corporations whereas Virginia Tech faculty do it in service to the state. Institutional loyalties divide us.

\section{| Haunted Rituals}

Complaints about disaster marathons are easy to understand, in view of the crass intrusions of the press and the different allegiance felt by faculty. But how shall we explain the more ceremonial language with which some came to hallow our own venues as sacred and imbue them with healing power? Such a response draws a line between good and evil - a demarcation that often results from moral discomfort. For this reason, I wonder if some marathons attain intensities sufficient to haunt their viewers. Gordon (1997) describes hauntings as animated states in which people grow aware of social tensions. Societies could well feel a strain between the payoffs and the price of violence against their citizens - the solidarity that memorials provide vs. the grief at our loss. What Marvin (2002) calls the "totem secret" bubbles beneath national awareness: the hidden knowledge that the group can gain from the killing of its members because it allows for celebration of their sacrifice (p. 205). During times of contested warfare, opposition parties proclaim that secret, as an accusation against the state of sending its young to die and then spending the political capital. After cases of unauthorized murder, the secret is better kept; most of those who benefit by memorial veneration can do so with a sense of innocence. (After all, they didn't elect the killers, even if they can enjoy the communal warmth that follows.) Still, the tension remains and perhaps appears when rituals grow most intense.

I suggest that the intrusions and focus on conflict that allow journalists to do their work risk unearthing citizens' investments in the rituals that follow disaster. Our discomfort under the cameras' glare may have tarnished the memorials by association. There is nothing terribly rational about hallowing classrooms as healing space or shunning journalists as the unwashed. Perhaps such thoughts occurred as part of local citizens' attempts to exorcise what haunts us. We want our fallen friends restored, and an end brought to our grief, yet basked in the glow of the rituals that honored their memories. We would trade those rites for a chance to bring back the dead, but could not and thus remained haunted as we joined in school cheers. The ghoulish solidarity might offend when viewed from the right vantage. To blame crass sensation on reporters could help to banish what troubles us. 
The dead animate civil religion, lifting survivors in solidarity. The role played by out-of-town, for-profit reporters in national rituals make them convenient targets of the scorn haunted by communal grief and guilt. This connection between rituals that foster solidarity, and the storytelling that enhances conflict and drama, came into focus in the days following this widely reported violence. The imperatives that drive professions differ enough that we can draw lines between us when so inspired; but where some faculty sought to resolve moral tension by posing classrooms as sacred, and repudiating journalists as infidels, I suggest a more dialectical relation of public education to private journalism.

\section{Endnotes}

1. Tactful reticence about their professional goals produced odd locutions among journalists. During a walk through the memorials on campus, my spouse and I were asked by a camera crew whether we were parents. After a pause, a reporter specified, "parents of children." As I wondered what other creatures we might have raised, it became clear that "children" had become code for those who had been shot, or at least for students at the university.

2. This focus on ritual may strike as odd those who either avoid language associated with sociological functionalists or share Benjamin's (1968) distrust of electronic reproduction. However, one need neither ignore social conflict nor be naïve about the force of media technology to note that groups employ rituals to mark their boundaries, affirm their rules, and generate solidarity (Collins 2004:12; Marshall 2002) - even in a late capitalist era, and in ways that can challenge ruling blocs (Cottle 2006; Liebes 1998).

3. As this article goes to press, a governor-appointed panel is revisiting commonwealth mental-health policies in light of this news.

4. Rohlinger (1998:139-40) also finds a journalistic taste for conflict in her study of abortion-debate coverage: the increased focus on profitable, rather than important, news has turned political and social coverage away from the deepest contexts toward the sharpest conflicts.

5. Spree killings might be reduced in frequency if news media deemphasized the glamour of those that occur. In order for this to work, reporters would mostly ignore such killings (as with television editors' decisions to cease broadcasting news of local teen suicides decades ago after a series of copycat waves followed such reporting). But journalists exercise no such restraint once incidents gain national attention. Spree killings are most often prevented when those who observe the antisocial behaviors of would-be killers share information and intercede. Such peers and teachers must trust law enforcement in order for this to work, which is why draconian lock-downs and zero-tolerance policies fail. Lock-downs don't separate killers from their intended victims. And zero-tolerance policies alienate trivial offenders from law enforcement, reducing the rate of tips that could alert authorities to serious threats. Finally, profiling cannot distinguish between young men who are just creepy and those who are planning sprees. In short, the most popular responses to spree killings do little to solve the problem.

6. One such legal motion to loosen handgun restrictions was denied in North Carolina as this article went to press.

\section{References}

Benjamin, Walter. 1968. Illuminations. New York:Harcourt Liebes, Tamar. 1998. “Television's Disaster Marathons: A Brace and World.

Collins, Randall. 2004. Interaction Ritual Chains. Princeton, N.J.: Princeton University Press.

----. 2004. "Rituals of Solidarity and Security in the Wake of Terrorist Attack." Sociological Theory 22:53-87.

Cottle, Simon. 2006. "Mediatized Rituals: Beyond Manufacturing Consent.” Media, Culture and Society 28:411-432.

Gordon, Avery. 1997. Ghostly Matters: Haunting and the Sociological Imagination. Minneapolis:University of Minnesota Press. Danger for Democratic Processes?” Pp. 71-84 in Media, Ritual, and Identity, edited by T. Liebes, J. Curran, and E. Katz. London:Routledge.

Marshall, Douglas A. 2002. "Behavior, Belonging, and Belief: A Theory of Ritual Practice." Sociological Theory 20:360-380.

Marvin, Carolyn. 2002. "Scapegoating and Deterrence: Criminal justice Rituals in American Civil Religion.” Pp. 203-18 in Practicing Religion in the Age of the Media: Explorations in Media, Religion, and Culture, edited by S. M. Hoover and L. S. Clark. New York:Columbia University Press. 
Rohlinger, Deana A. 2007. "American Media and Deliberative Walter, Tony, Jane Littlewood, and Michael Pickering. 1995. Democratic Processes." Sociological Theory 25:122-148. "Death in the News: The Public Invigilation of Private Sumiala-Seppanen, Johanna and Matteo Stocchetti. 2007. "Father of the Nation or Arch-terrorist? Media Rituals and Images of the Death of Yasser Arafat." Media, Culture and Emotion." Sociology: The Journal of the British Sociological Society 29:336-343. 